\title{
Recovery and examination of sculpture group Fugitive Slave by V. Beklemishev
}

\author{
Kamilla B Kalinina ${ }^{1 *}$, Sander Habets², Evelina A Tarasova ${ }^{1}$ and Svetlana L Petrova ${ }^{1}$
}

\begin{abstract}
Background: On the $26^{\text {th }}$ of April 2010, while performing routine electrical work, a lost sculpture group of famous Russian sculptor Vladimir Beklemishev (1861-1920) titled 'Fugitive Slave' was found inside a wall of the Winter Palace in St. Petersburg, Russia on the landing of the staircase to the second floor. This sculpture was created under the influence of the anti-slavery novel "Uncle Tom's Cabin" by American author Harriet Beecher Stowe and was presented at the World's Columbian exposition in Chicago in 1893, devoted to the $400^{\text {th }}$ anniversary of the discovery of America by Columbus. The sculpture was made from gypsum and coated with a covering that imitated bronze. At the moment of finding, the sculpture was heavily damaged and needed serious restoration, including repairing of the bronze imitation layer. This situation permitted us to do a detailed examination of the materials and techniques used in making this bronze-like covering. The sculpture was made by Beklemishev in Italy in 1891. At the time of writing, 'Fugitive Slave' has been restored to its former glory and can be admired in the State Hermitage museum in St. Petersburg, Russia.

Results: Studying the cross-sections of tiny fragments of bronze-like covering from different parts (bright and dark) showed that the coating was multilayered. Different parts of the covering also show large differences in structure. Pigment composition of each layer was investigated by SEM-EDS (Scanning Electron Microscopy-Energy Dispersive Spectroscopy). Relatively pure copper filings and scrapings were applied to imitate a solid bronze layer. The top thin layer, which imitated a bronze patina, was made of a copper arsenic paint.

GC/MS analysis of the fatty acids showed the presence of drying oil. The presence of erusic acid, a biomarker, showed presence of the Brassicaceae seed oil. A small amount of pinaceous resin and dammar were discovered as well. The top thin layer, however, seemed to contain linseed oil (based on fatty acids ratios - $A / P=1.5 ; P / S=1.6$ ). Besides that, the surfaces of the dark parts were covered with a very thin layer of beeswax. It is believed that this is the result of conservation treatment, rather than applied by Beklemishev himself.

PCA analysis of the selected ion monitoring chromatograms of the proteinaceous materials showed the presence of egg in practically all layers of bright fragments and in the bottom layers of the dark fragments. According to literature, a mixture of drying oil, egg and resins was often used for priming in polychromic paints on stone in Italy. Since Beklemishev made 'Fugitive Slave' during his time there, it is possible that he used these materials. However, looking at the middle layers of the dark fragments, evidence for casein as proteinaceous ingredient was also found. Since the layers where casein was found are thicker, the presence of casein indicates that a casein-oil mixture was possibly applied as binding to get more pasty paint films. This way one may conclude that different binding materials were used for different layers.
\end{abstract}

Conclusions: These analyses give a great insight into the way imitation of bronze of this sculpture was made and allow us to learn more about this specific technique.

Keywords: Pigments, Binding media, Sculpture, Imitation of bronze, SEM-EDX, GC-MS, Fugitive slave, Vladimir Beklemishev

\footnotetext{
* Correspondence: Kkalinina@hermitage.ru

${ }^{1}$ The State Hermitage Museum, Saint Petersburg, Russia

Full list of author information is available at the end of the article
} 


\section{Introduction}

Vladimir Beklemishev graduated from the Saint Petersburg Imperial Academy of Arts with a Grand gold medal in 1887 [1]. He was a pensioner of the Academy of Fine arts in Paris and Rome in 1888-1892. He made the sculptural group "Fugitive Slave" in Italy in 1890-1891. The undoubted source of inspiration for V. Beklemishev was "Slaves" by Michelangelo (Florence, Museum of the Academy of fine arts).

This sculpture was created under the influence of the anti-slavery novel "Uncle Tom's Cabin" by American author Harriet Beecher Stowe, who was very popular this period of time. Together with the paintings of famous Russian artists such as I. I. Levitan, V. A. Serov, I. E. Repin, V. I. Surikov, sculptural group "Fugitive Slave" was presented at the World's Columbian exposition in Chicago in 1893 , devoted to the $400^{\text {th }}$ anniversary of the discovery of America by Columbus [2]. After the exposion, the sculpture was gifted to the Museum of Saint Petersburg Imperial Academy of Arts in 1918, which later donated it to the State Museum of the Great October Revolution in 1930. After the Second World War (1941-1945), the Museum of the Great October Revolution got its own building (a mansion of M. Kshesinskaya) where "Fugitive Slave" was to moved to. The sculpture group was however heavily damaged during this transition. As a consequence of this damage, the decision was made for the sculpture to be stored between walls of the Eastern Gallery staircase of the Winter Palace and the Church in February 22, 1947, as explained by a note that was found with the statue. No other record of this decision was made, so in time, the location of the "Fugitive Slave" sculpture was forgotten and the statue was eventually considered lost or even destroyed. However, in April 2010, while performing routine electrical work, the sculpture group was once again discovered, virtually in the same state as it was stored decades before.

The sculpture is made from gypsum and coated in a bronze imitated covering. At the moment of finding, the sculpture was heavily damaged and needed serious restoration, including repairs of the bronze imitated layer. This situation permitted us to do a detailed examination of the materials and techniques used in making this bronze-like covering.

This paper examines the pigments and binding media by used Vladimir Beklemishev for creating the bronze-like layers.

The study was performed on several samples from different parts of the sculpture by means of optical microscopy under visible illumination, Scanning Electron Microscopy (SEM) coupled with energy-dispersive X-ray spectroscopy (SEM-EDX) and Gas chromatography-mass spectrometry (GC-MS). Optical microscopy and SEM of the sample cross-sections revealed the layer by layer build-up of each sample. The combination of optical microscopy and SEM with EDX, allowed for identification of most of the pigments that were used. GC-MS was used for the analysis of proteins, glycerolipids, waxes, and terpenoid resins. This enabled various organic materials to be identified by marker recognition, molecular profile identification, and quantitative evaluation.

\section{Materials and methods Equipment}

A Trace GC System Gas Chromatograph (ThermoFinnigan, USA), coupled with a Mass Selective Detector single quadrupole mass spectrometer equipped with a Programmed Temperature Vaporization Injector (PTV) was used. The mass spectrometer was operated in the EI positive mode $(70 \mathrm{eV})$. The MS transfer line temperature was $270^{\circ} \mathrm{C}$ and the MS quadrupole temperature $170^{\circ} \mathrm{C}$. For the gas chromatographic separation, an HP-5MS fused silica capillary column (5\%diphenyl-95\%dimethyl-polysiloxane, 30m $\times$ $0.25 \mathrm{~mm}$ i.d., $0.25 \mathrm{~mm}$ film thickness, J\&W Scientific, Agilent Technologies, Palo Alto, CA, USA) coupled with a deactivated silica pre-column ( $2 \mathrm{~m}$ X $0.32 \mathrm{~mm}$ i.d., J\&W Scientific Agilent Technologies, Palo Alto, CA, USA) with a quartz press fit was used. The carrier gas was helium (purity $99.995 \%$ ) at a constant flow of $1.2 \mathrm{ml} / \mathrm{min}$.

For the analysis of the lipid resinous fraction, the PTV injector was used in splitless mode at $290^{\circ} \mathrm{C}$. The chromatographic oven was programmed as follows: initially the oven would be kept at $50^{\circ} \mathrm{C}$ for 2 minutes, followed by an increase in temperature of $8^{\circ} \mathrm{C} / \mathrm{min}$ up to $290^{\circ} \mathrm{C}$, after which the temperature was kept at $290^{\circ} \mathrm{C}$ for 30 minutes. For the analysis of silylated amino acids the PTV injector was used in splitless mode at $220^{\circ} \mathrm{C}$ and the chromatographic oven was programmed as follows: initially $100^{\circ} \mathrm{C}$ for $2 \mathrm{~min}$, then $4^{\circ} \mathrm{C} / \mathrm{min}$ up to $280^{\circ} \mathrm{C}$ and concluded with an isothermal period at $280^{\circ} \mathrm{C}$ for $15 \mathrm{~min}$.

A LEO 1420VP scanning electron microscope (SEM) was used. This was equipped with a Rontec energy dispersive X-ray spectrometer (EDX). SEM conditions were as follows: $25 \mathrm{kV}$, beam current optimized for EDX analysis, working distance $13 \mathrm{~mm}$. Samples were examined in lowvacuum and the SEM chamber pressure was set at $30 \mathrm{~Pa}$.

Polarized light microscopy (PLM) was used in transmitted and reflected light mode with a microphotography capability (POLAM-211). The stereomicroscopes that were used were the MBS-2 and the Nikon SMZ 800.

\section{Preparation of cross-sections from the samples for the microscopy techniques}

The samples were first observed under the stereomicroscope. Cross-sections of the samples were made by mounting a sample aliquot in polyester resin "Clear Casting AM" (orthophthalic, acrylic modified Clear Casting Resin, UK). After grinding the polymer block to size with Buehler-met metallographic grinding paper, the surface 
was further dry-polished with a Polishing Cloth Texmet 1000 non-woven pad (Buehler-Met GmbH, Germany).

\section{GC-MS analytical procedure}

Before GC-MS analysis the sample was divided into lipid and protein fractions. For this purpose the sample was extracted with $2.5 \mathrm{M} \mathrm{NH}_{3}\left(3 \mathrm{~h}, 60^{\circ} \mathrm{C}\right)$ twice in an ultrasonic bath to extract the proteinaceous binders. The sample was then centrifuged, the supernatant ammonia solution separated, and the extracted solutions were joined together. The residue containing insoluble organic (i.e. lipid and resinous materials) and inorganic species was kept apart. The extracted ammonia solution, containing proteins and peptides, was evaporated to dryness and subjected to acidic hydrolysis with $6.0 \mathrm{M} \mathrm{HCl}$ $\left(24 \mathrm{~h}, 105^{\circ} \mathrm{C}\right)$. After hydrolysis, bidistilled water was added to the acidic hydrolysate, which constitutes the amino acid fraction. An aliquot of the amino acid fraction was then analysed by GC-MS after derivatisation with $N$-methyl$N$-(tert-butyldimethylsilyl)trifluoroacetamide) (MTBSTFA), using norleucine as internal standard, pyridine as a solvent, and triethylamine as a catalyst. Further analytical procedure is described in ref. [3]. The residue after the ammonia extraction was subjected to saponification/salification with $\mathrm{KOH}$ in ethanol. After saponification, the alcoholic solution was diluted in bidistilled water, acidified with trifluoroacetic acid, and extracted with $n$-hexane (three times) and diethyl ether (three times). The organic extracts (containing fatty acids, dicarboxylic acids, terpenoid acids, alcohols, phenols, hydrocarbons and other neutral and acidic substances deriving from the lipid and resinous fractions of the sample) constituted the lipid-resinous fraction. An aliquot of the lipid-resinous fraction was analysed by GC-MS after derivatisation with $\mathrm{N}, \mathrm{O}$-bistrimethylsilyltrifluoroacetamide (BSTFA), using isooctane as a solvent.

\section{Samples}

Investigation of samples of the bronze-like covering from different parts of the statue the stereomicroscope showed that they had a very different surface structure. The covering from the 'exposed' part of the statue was lighter and brighter that the covering found in the folds of the statue (less exposed). While the first had a bright bronze tinge, the second was practically black. Sampling points from "Fugitive Slave" are showed in Figure 1.

This difference is clearly shown in Figure 2, where photos from the samples under a stereomicroscope with a magnification of 50 times show the differences between the two kinds of covering that were used by Beklemishev.

\section{Analytical results Inorganic materials}

An investigation into the inorganic pigments was performed on the two different kinds of bronze-like layer by studying cross-sections from the sample using PLM microscopy and SEM-EDX.

SEM-EDX allowed for identification of the pigment composition of each layer. The dark field images of the crosssections of two different samples from the "Fugitive Slave" under PLM microscopy and the corresponding SEM back scattered electron images are reported in Figure 3. The two samples proved to have a very different structure. While the bright sample (from an exposed part of the statue) had four coloured layers, a sample from the darker part (less exposed) consisted of about eight layers (see Figure 3).

The interpretations of the PLM and SEM-EDX investigations are summarised for each sample, layer by layer, in Table 1.

The investigation of the two cross-sections under the microscope and the study of pigment composition by using the SEM-EDX revealed that the four layers of the first cross-section (bright) are also present on the lower part of second cross-section (dark). The build-up is identical as well: the lowest layer is a basic white gypsum layer containing calcium. On top of this layer, a thin brown layer consisting of a mixture of thinly ground gypsum and iron earth pigments was applied. This layer was then covered with an orange layer of lead red, after which another mixture of ground gypsum and iron earth pigments was applied. This time, however, this mixture also contained

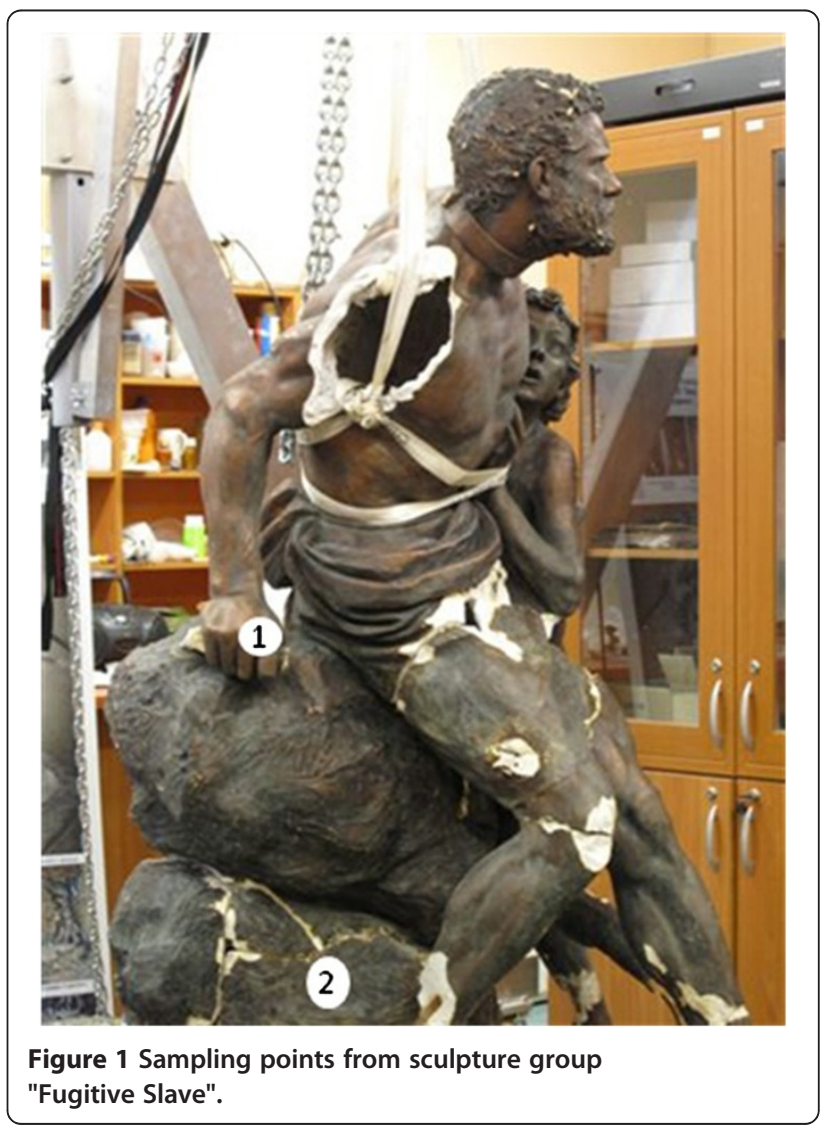



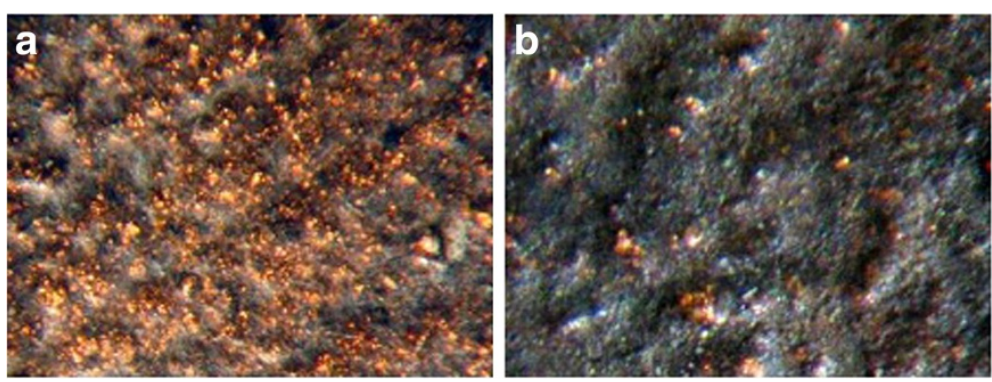

Figure 2 Images of bright (exposed) part (a) and dark (less exposed) part (b) of the bronze-like covering of the sculpture surface under stereomicroscope with a magnification of 50 times.

copper filings or scrapings. In the darker sample, even more (but similar) layers were applied, but the basic structure described above is present in both samples.

The EDX spectrum of the copper containing layers found in the cross-sections of both samples permitted to conclude that the imitation of bronze in the upper layers was achieved by mixing pure copper filings (about $5 \mu \mathrm{m}$ ) into the mix. A solid bronze layer was not applied. The top thin layer on the absolute surface of this covering was made of copper arsenic. Pigments contained copper and arsenic, Sheele's green and Emerald green and have a general green colour [4]. Obviously, this layer was applied for imitation of patina.

As it was showed on Figure 3 (c, d) the thin layer of copper arsenic of darker parts of the statue was covered with even more layers that consisted of a mixture of thinly ground gypsum and iron earth pigment, followed by layer of mixture of red and white lead. Then layers of copper scrapings and copper arsenic were applied. It seems that the darker parts of the statue were constructed by applying the same order of layers twice, making these parts of the covering of the statue about twice as thick.
It is necessary to note that scrapings in all cases had the same size and composition.

\section{Organic materials \\ Proteinaceous materials}

To identify the binding media, the relative percentage content of amino acids in each sample was compared to those from a dataset of samples of egg, casein and animal glue. In literature, it has often been shown that the origin of the binding material can be deduced from the composition of aminoacids. For example, animal glue has a relatively high concentration of alanine and glycine, while egg (either egg white or egg yolk) contain a relatively high amount of valine, leucine and isoleucine. Principal Component Analysis (PCA) was performed on the correlation matrix of the relative percentage contents of twelve amino acids (Ala, Gly, Val, Leu, Ile, Met, Ser, Pro, Phe, Asp, Glu, Hyp). The resulting score plots are reported in Figure 4.

The PCA revealed that egg was present as a protein component of binding of bright fragment of coating (point1). According to the analysis egg also was observed in the protein fraction of binding material of the lower
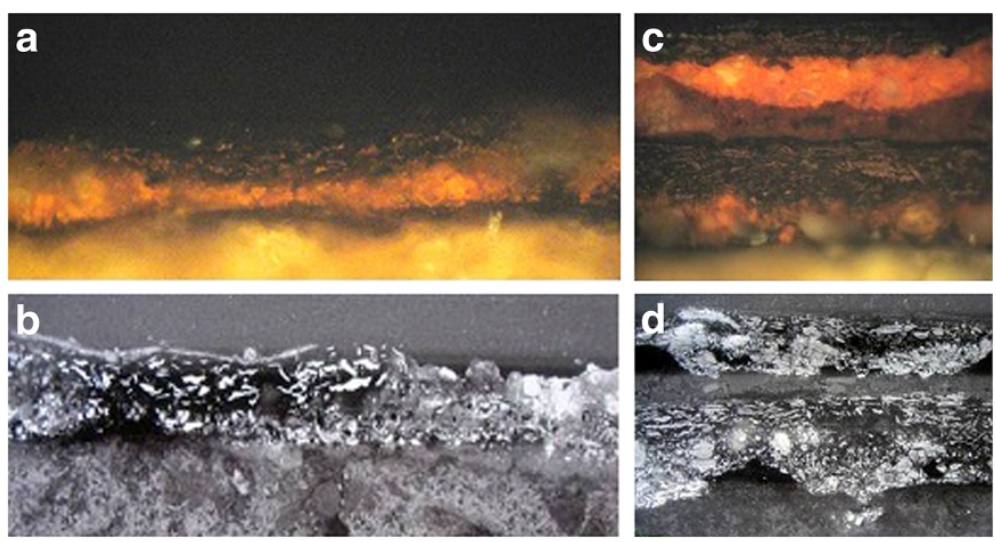

Figure 3 Cross sections of bright and dark samples of the bronze- like covering from the "Fugitive Slave": a) dark field (white light) image of cross-section of the bright part; b) SEM-BSE image of cross-section of the bright part; c) dark field (white light) image of cross-section of the dark part; d) SEM-BSE image of cross-section of the dark part. 
Table 1 Bronze-like covering: results of the PLM and SEM-EXD investigation on inorganic pigments

\begin{tabular}{|c|c|c|c|}
\hline Sample & Layer & $\begin{array}{l}\text { Elements detected by } \\
\text { SEM-EDX }\end{array}$ & $\begin{array}{l}\text { Suggested pigments and } \\
\text { minerals }\end{array}$ \\
\hline \multirow[t]{6}{*}{ Bright } & lower white layer & $\mathrm{Ca}, \mathrm{S}$ & gypsum \\
\hline & lower dark brown layer & $\mathrm{Si}, \mathrm{Fe}, \mathrm{Ca}, \mathrm{S}, \mathrm{K}$ & $\begin{array}{l}\text { mixture of gypsum and iron } \\
\text { earth pigment }\end{array}$ \\
\hline & orange layer & $\mathrm{Pb}$ & lead red \\
\hline & dark brown layer & $\mathrm{Si}, \mathrm{Al}, \mathrm{Fe}, \mathrm{Ca}, \mathrm{S}, \mathrm{Mg}, \mathrm{K}$ & $\begin{array}{l}\text { mixture of gypsum and iron } \\
\text { earth pigment }\end{array}$ \\
\hline & bright orange chips & $\mathrm{Cu}$ & copper filings \\
\hline & uppermost very thin layer & $\mathrm{Cu}$, As & copper arsenic \\
\hline \multirow[t]{11}{*}{ Dark } & lower white layer & $\mathrm{Ca}, \mathrm{S}$ & gypsum \\
\hline & lower dark brown layer & $\mathrm{Si}, \mathrm{Fe}, \mathrm{Ca}, \mathrm{S}, \mathrm{K}$ & $\begin{array}{l}\text { mixture of gypsum and iron } \\
\text { earth pigment }\end{array}$ \\
\hline & orange layer & $\mathrm{Pb}$ & lead red \\
\hline & dark brown layer & $\mathrm{Si}, \mathrm{Al}, \mathrm{Fe}, \mathrm{Ca}, \mathrm{S}, \mathrm{Mg}, \mathrm{K}$ & $\begin{array}{l}\text { mixture of gypsum and iron } \\
\text { earth pigment }\end{array}$ \\
\hline & bright orange of chips & $\mathrm{Cu}$ & copper filings \\
\hline & intermediate very thin layer & $\mathrm{Cu}, \mathrm{As}$ & copper arsenic \\
\hline & thick dark brown layer & $\mathrm{Si}, \mathrm{Al}, \mathrm{Fe}, \mathrm{Ca}, \mathrm{S}, \mathrm{Mg}, \mathrm{K}$ & mixture of gypsum and iron earth pigment \\
\hline & orange layer with white inclusions & $\mathrm{Pb}$ & mixture of lead red and white lead \\
\hline & bright orange of chips & $\mathrm{Cu}$ & copper filings \\
\hline & upper dark brown layer & $\mathrm{Si}, \mathrm{Al}, \mathrm{Fe}, \mathrm{Ca}, \mathrm{S}, \mathrm{Mg}, \mathrm{K}$ & mixture of gypsum and iron earth pigment \\
\hline & uppermost very thin layer & $\mathrm{Cu}, \mathrm{As}$ & copper arsenic \\
\hline
\end{tabular}

For each sample, the layers are discussed from bottom to top.

layers of the dark fragment (point 2) of the bronze imitation covering. Protein fraction of the upper layers of the dark fragment contained casein (point 3) given their position in the score plot.

It should be noted here that while the lipid fractions were individually studied for each layer (see next section), this is not the case for the proteinaceous material. Here, only three samples (not necessarily a single layer, but rather a combination of layers) were studied. During the time that the proteinaceous materials were being studied, the used GC-MS developed problems. This severely reduced the amount of samples that could be studied in the available amount of time. Therefore, the authors chose to investigate the layers in bulk in an attempt to produce some results about the proteinaceous content of the samples.

However, this did provide some interesting results nonetheless. In particular the result that the bright sample and the lower part of the dark sample (which already showed to have the same build-up of layers) also contain the same proteins is very interesting. It's also good to note that the upper part of the dark sample (point 3) apparently contains proteins from a different source.

\section{Lipid and resinous materials}

The GC-MS analyses revealed the presence of lipid and resinous materials in both samples.
Figure 5 reports the chromatogram of the lower dark layer of the bright sample of bronze-like covering.

The identification of the source of the lipid materials was based on the parameters A/P (ratio between azelaic acid and palmitic acid), $\mathrm{P} / \mathrm{S}$ (ratio between palmitic acid and stearic acid), and $\Sigma \mathrm{D}$ (the sum of dicarboxylic acids) [3]. The identification of resinous materials was based on the presence of appropriate biomarkers, which were dehydroabieic acid and 7-oxo-dehydroabietic acid for a resin from Pinaceae, while 20-24-epoxy-25-hydroxy-dammaren-3-one was used as a marker for dammar. Beeswax was identified on the basis of its monocarboxylic acids and hydrocarbon profiles [3]. Chromatographic analysis revealed the presence of linear monocarboxylic acids with an even number of carbons (ranging from 12 to 34 atoms and showing a maximum in the chromatogram for palmitic acid $\left(C_{16}\right)$ ). At the same time, the profile of long chain fatty acids shows maximums for tetracosanoic acid $\left(\mathrm{C}_{23} \mathrm{H}_{47} \mathrm{COOH}\right)$, 15-hydroxyhexadecanoic acid, 17-hydroxyoctadecanoic acid and fractions of long-chain linear hydrocarbons with an odd number of carbons (ranging from 23 to 33).

The results are summarised in Table 2 .

GC/MS analysis of fatty acids revealed the presence of drying oil $(\mathrm{A} / \mathrm{P}>1$ and $\Sigma \mathrm{D}>40)$. The presence of erucic acid, a biomarker for Brassicaceae seed oil [5-7], shows that it is likely that this specific type of oil was used. 


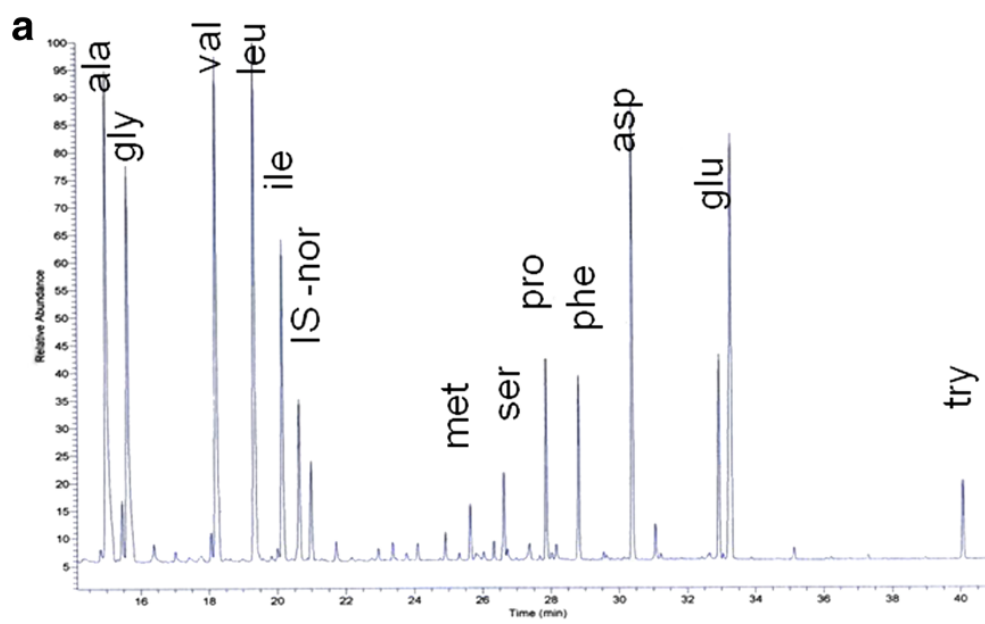

b
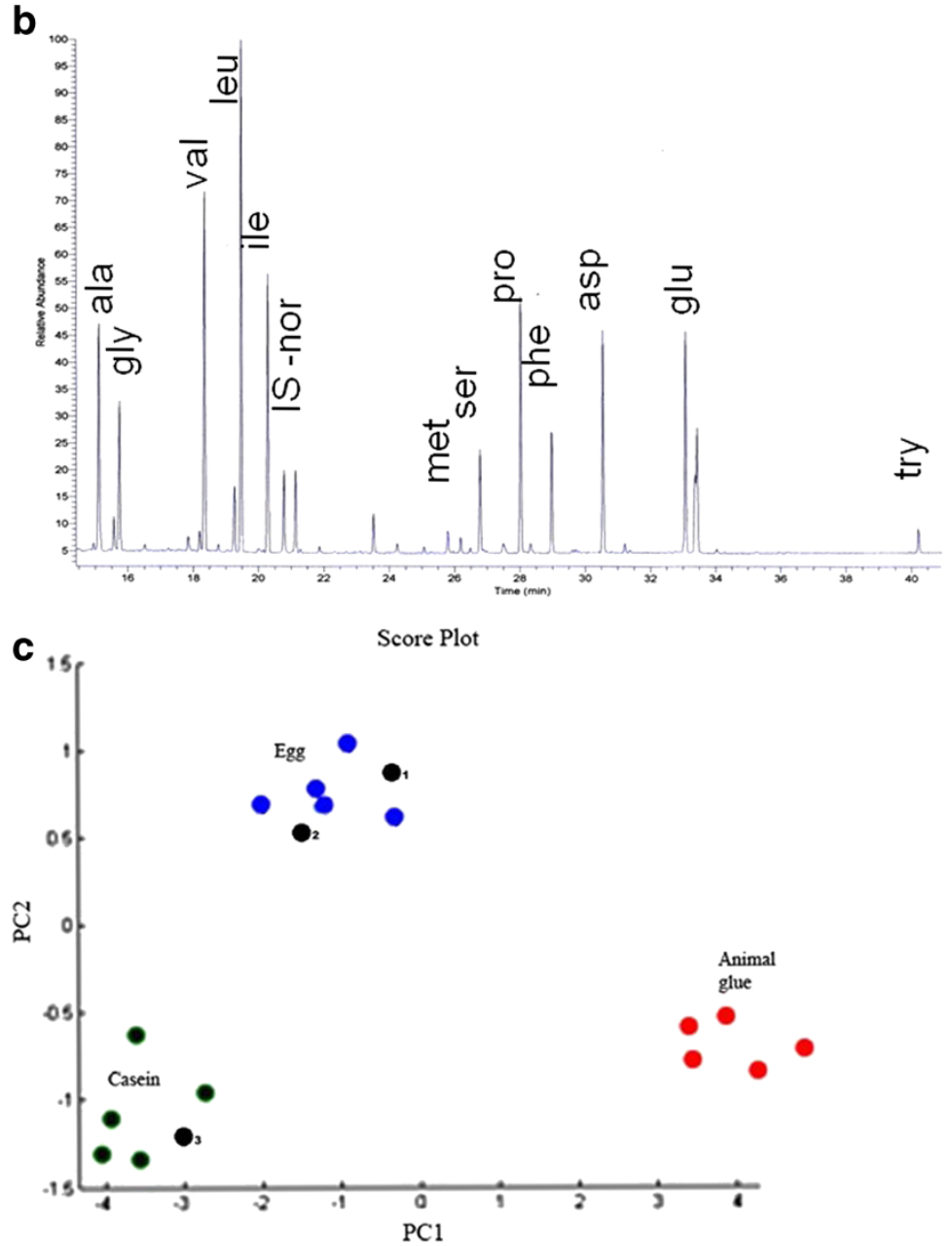

Figure 4 (a) - Selected ion monitoring chromatograms of amino acid derivatives in bright fragment; (b) - Selected ion monitoring chromatograms of amino acid derivatives in bright fragment; (c) - PCA score plot of the samples collected from different parts of the bronze imitating covering: 1 - the bright fragment; 2 - bottom part of the dark fragment; 3 - top part of the dark fragment. 


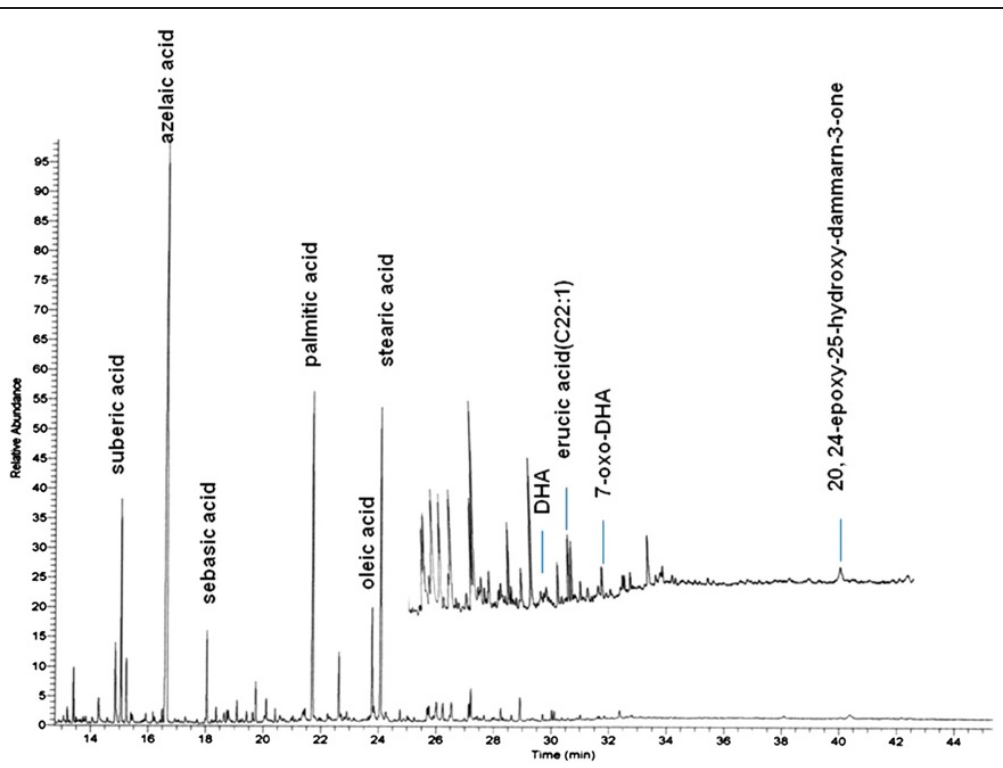

Figure $\mathbf{5}$ Chromatogram of the lipid-resinous fraction of lower dark layer of bright sample.

Table 2 Results of the analysis of the lipid-resinous fraction of different layers of bronze imitating covering of "Fugitive Slave"

\begin{tabular}{|c|c|c|c|c|c|c|c|c|c|}
\hline Sample & Layer description & $A / P$ & $\mathrm{P} / \mathrm{S}$ & $\sum D$ & Erucic acid & Beeswax & Pinaceae resin & Dammara & Composition \\
\hline \multirow[t]{4}{*}{ Bright } & 1.brown bottom & 2.7 & 0.9 & 61.2 & + & - & + & + & $\begin{array}{l}\text { Brassicaceae seed } \\
\text { oil + Pinaceous } \\
\text { resin + dammar }\end{array}$ \\
\hline & 2.orange thick & 0.9 & 0.9 & 40.4 & + & - & + & + & $\begin{array}{c}\text { Brassicaceae seed } \\
\text { oil + Pinaceae } \\
\text { resin + dammar }\end{array}$ \\
\hline & $\begin{array}{l}\text { 3.upper brown with } \\
\text { bright orange inclusions in } \\
\text { the form of chips }\end{array}$ & 0.7 & 1.2 & 31.8 & + & - & + & + & $\begin{array}{l}\text { Brassicaceae seed } \\
\text { oil + Pinaceous } \\
\text { resin + dammar }\end{array}$ \\
\hline & 4.transparent thin top & 1.2 & 1.5 & 50.7 & - & - & + & - & $\begin{array}{l}\text { Linseed oil }+ \\
\text { Pinaceous resin }\end{array}$ \\
\hline \multirow[t]{8}{*}{ Dark } & 1.brown bottom & 2.0 & 1.0 & 47.0 & + & - & + & + & $\begin{array}{l}\text { Brassicaceae seed } \\
\text { oil + Pinaceous } \\
\text { resin + dammar }\end{array}$ \\
\hline & 2.orange thick middle & 0.8 & 1.3 & 37.5 & + & - & + & + & $\begin{array}{c}\text { Brassicaceae seed } \\
\text { oil + Pinaceous } \\
\text { resin + dammar }\end{array}$ \\
\hline & $\begin{array}{l}\text { 3.brown thick middle } \\
\text { with bright orange inclusions } \\
\text { in the form of chips }\end{array}$ & 0.8 & 1.2 & 27.7 & + & - & + & + & $\begin{array}{l}\text { Brassicaceae seed } \\
\text { oil }+ \text { Pinaceous } \\
\text { resin }+ \text { dammar }\end{array}$ \\
\hline & 4.thick brown intermediate layer & 0.9 & 1.1 & 25.6 & + & - & + & + & $\begin{array}{c}\text { Brassicaceae seed } \\
\text { oil }+ \text { Pinaceous } \\
\text { resin }+ \text { dammar }\end{array}$ \\
\hline & 5.thick middle orange & 0.6 & 1.0 & 23.0 & + & - & + & + & $\begin{array}{l}\text { Brassicaceae seed } \\
\text { oil + Pinaceous } \\
\text { resin + dammar }\end{array}$ \\
\hline & $\begin{array}{l}\text { 6.thin top brown with } \\
\text { bright orange inclusions in } \\
\text { the form of chips }\end{array}$ & 1.0 & 1.4 & 37.0 & + & - & + & + & $\begin{array}{l}\text { Brassicaceae seed } \\
\text { oil + Pinaceous } \\
\text { resin + dammar }\end{array}$ \\
\hline & 7.transparent thin top & 0.9 & 1.6 & 27.0 & - & - & + & - & $\begin{array}{l}\text { Linseed oil }+ \\
\text { Pinaceous resin }\end{array}$ \\
\hline & 8.upper surface covering (from cracks) & & & & & + & & & Beeswax \\
\hline
\end{tabular}


Small amounts of pinaceau resin and dammar were also found. The top thin layer of copper arsenic, however, seemed to contain linseed oil. This was estimated from the ratios of $\mathrm{A} / \mathrm{P}=1.5 ; \mathrm{P} / \mathrm{S}=1.6$. Erucic acid wasn't found in this layer. Besides that, a very thin layer of beeswax covered the surfaces of parts of the darker sample: chromatographic profile of this layer demonstrated the presence of monocarboxylic acids C22-C30 with a maximum for $\mathrm{C} 26$ and fractions of odd hydrocarbons C23-C31 with a maximum for C27.

\section{Results and discussion}

After the discovery of the sculpture, it was clearly apparent that it was badly damaged and that it needed major conservation treatment, including necessary restorations of the bronze-like covering on the surface. However, before conservation could be carried out, it was necessary to understand the techniques behind the creation of this bronze-like layer. Next to that, the used materials also needed to be identified to investigate whether the clearly visible difference of colours in different parts of the sculpture were caused by the original development by Beklemishev or subsequent conservation or restoration treatments.

Studying the cross-sections from different parts of the statue using SEM revealed that the appearance of a bronzelike covering was achieved by consistently applying brown and orange layers with addition of pure copper filings and scrapings rather than actual bronze, as one would expect. To produce the appearance of natural patina the thin greenish copper arsenate (Sheele's green or Emerald green) paint layer was applied on top of the coating.

PLM and SEM-EXD investigations of the inorganic materials in both the bright and dark fragments also showed that the same inorganic materials are present in both layers, while the difference in colour shades (bright and dark) arises due to differences in thickness and amount of coloured layers. While this approach to establishing a bronze-like covering was clearly the sculptor's own idea, traces of subsequent conservation treatments can be found in a thin surface layer, where materials (like beeswax) were found that were not present in any other part of the sculpture. These conservation traces were mostly found in cracks of the dark parts, so it is believed that these materials are only present in these specific areas where damage to the sculpture has occurred.

According to the SEM data reported in this research, the priming layer for the bronze imitation on the "Fugitive Slave" consisted of a mixture of gypsum and iron earth pigment. This is similar in composition to results reported for the polychrome roundels and capital of the S. Ambrogio Basilica's Portal, where the paint was applied directly on the marble substrate using mixtures of yellow, red, and green colourants and gypsum [8]. The authors of that publication also concluded that the yellow, red, and green colouring agents were applied in mixture with egg tempera and an addition of gypsum to make the layers on stone substrate more firm and, probably, more stable. A similar composition of painting layers, with high gypsum content, has been also found in some areas of S. Fermo Maggiore Church in Verona.

This, however, does not perfectly match up with 'standard' Italian procedures during Beklemishev's stay there. Especially since the sculpture itself was also created in Italy, one would naturally expect that the sculptor used materials and technical approaches typical for Italian polychromic stone sculptures in that time. In regards to this "Italian tradition", it is important to note that the Manuscript by Cennino Cennini (XIV century) [9] contains a brief paragraph regarding stone bases (like gypsum). Cennini wrote that the binding medium of choice to be used on stone was oil. In particular, in describing methods for gilding stones, he also suggests a pre-treatment of the stone with animal glue. This is then followed by covering the stone with a protective mixture of linseed oil, resins and finely ground carbon dust. This mixture is applied twice and the second time some egg yolk is also added. Some published analytical data indeed show there were numerous cases where a priming layer of lead white and an oil mixture was discovered to be applied on a stone surface that was first pre-treated with animal glue [10-13]. At the same time certain papers report the absence of a pretreatment of the stone with glue demonstrating analytical evidence of the direct application of a priming layer of lead white in oil or proteinaceous materials. It is worth mentioning that very small amount of egg can be added to the oil medium [14-16].

However, this lead white and oil priming layer was completely absent in all the fragments taken from the statue, showing that Beklemishev did not follow 'traditional' procedures while creating 'Fugitive Slave'. Still, it was also discovered that the binding medium of the brown bottom layers, which are found on the surface of gypsum in bright and dark fragments, contained Brassicaceae seed oil with small additions of pinaceous resin and dammar. In accordance with literature [17], pine resin and drying oil were the main ingredients in the black decorations on marble panels in the chapel of the tomb of Saint Anthony (Padua, Italy), so this recipe is not entirely unique. These drying oil and mixture of drying oil, egg and resins were used often used both for priming and for colour layers in polychromic paints on stone in Italy. At this point, it is believed that Beklemishev used all the knowledge at his disposal to create his own, personal recipes to achieve the specific look he had in mind for "Fugitive Slave".

Analysis of the proteinaceous materials using Principal Component Analysis showed the presence of small amounts of egg in the next two layers of both kinds of fragments as 
well. This matches the literature in references 14, 15, 16 and [18] in which it is reported that egg was often used as an additive to the oil-based priming mixture. However, Beklemishev again did not follow the 'standard' procedure, since no evidence of animal glue was found. Therefore, it can be deduced that he did not pre-treat the base with animal glue as described in references 9 through 12 .

Studying of the composition of the binding medium in the upper layers of the dark fragment showed that an oil mixture containing casein was applied to obtain more thick and pasty paint. It is believed that this was done by Beklemishev to strengthen the vulnerable parts of the statue (folds etc.).

\section{Conclusions}

Through study of the organic and inorganic materials of the bronze-like covering it was possible to identify the different components and substances that were used. Through this, it was revealed that the techniques used by V. Beklemishev in his 'Fugitive Slave' were, to a certain extent, based on the experience accumulated by Italians in creating polychrome sculptures. Since "Fugitive Slave" was created during his time in Italy, this does not come as a surprise. However, Beklemishev did make significant changes to the composition and components of the mixtures in order to achieve the result he had in mind. Next to that, he applied a relatively new technique to create a bronze-like covering.

The studying of the structure, pigments and composition of binding medium of different layers prove that the upper layers of the darker parts were also applied by V. Beklemishev himself because these layers had the same pigment composition as the lower layers (as shown by SEM). Earlier conservation treatments were limited to already damaged parts of the sculpture and were shown to be have little consequence for the restoration of the sculpture.

Using the knowledge gained through this research, the sculpture was restored by curators of the State Hermitage museum.

At the time of writing, the 'Fugitive Slave' has been restored to its former glory and can be admired in the State Hermitage museum in St. Petersburg, Russia.

\begin{abstract}
Abbreviations
SEM-EDX: Scanning Electron Microscopy-Energy Dispersive X-ray Microanalysis; GC/MS: Gas Chromatography/Mass Spectrometry; PTV: Programmed Temperature Vaporization Injector; PLM: Polarized light microscopy; BSTFA: N,O-bis(trimethylsilyl) trifluoroacetamide; MTBSTFA: $N$-methyl-N-(tert-butyldimethylsily)trifluoroacetamide; TMCS: Trimethylchlorosilane; A: Azelaic acid; P: Palmitic acid; D: Dicarboxylic acids.
\end{abstract}

\section{Competing interests}

The authors declare that they have no competing interests.

\section{Authors' contributions}

All authors contributed to data analyses and to finalizing the manuscript. All authors have read and approved the final version. All authors read and approved the final manuscript.

\section{Acknowledgements}

Alex Kossolapov, a head of Department for Scientific Examination of Work of Art of the State Hermitage Museum, is acknowledged for useful discussion of the data.

\section{Author details}

${ }^{1}$ The State Hermitage Museum, Saint Petersburg, Russia. ${ }^{2}$ Analytical

Chemistry, Radboud University, Nijmegen, the Netherlands.

Received: 22 February 2013 Accepted: 27 February 2013

Published: 3 April 2013

\section{References}

1. The State Tretyakov Gallery. Catalog of the collection: Sculpture of XVIII-XX centuries. T. 1. Sculpture of XVIII-XIX centuries, Moscow, Red Square 2000, 1:108.

2. Catalogue of the Russian section, World's Columbian exposition, 1893, Chicago. St. Petersburg: I. Liebermann; 1893.

3. Colombini MP, Giachi G, Modugno F, Pallecchi P, Ribechini E: Characterisation of paints and waterproofing materials of the shipwrecks found in the archaeological site of the Etruscan and Roman harbour of Pisa (Italy). Archaeometry 2003, 45:649-664.

4. Fiedler I, Bayard MA: Artist's Pigments. A Handbook of Their History and Characteristics, Washington D.C 1997, 3:219.

5. Goffman FD, Thies W, Velasco L: Chemotaxonomic value of tocopherols in Brassicaceae. Phytochemistry 1999, 50:793.

6. Baggi E, Ozcelik H: Fatty Acid and Tocochromanol Patterns of some Isatis L. (Brassicaceae) Species from Turkey. Pak J Bot 2009, 41(2):639-646.

7. Colombini MP, Modugno F, Ribechini E: Organic mass spectrometry in archaeology: evidence for Brassicaceae seed oil in Egyptian ceramic lamps. J Mass Spectro 2005, 40:890-898.

8. Casadio F, Colombo C, Sansonetti A, Toniolo L, Colombini MP: Polychromy on stone bas-reliefs:the case of the basilica of Saint-Ambrogio in Milan. J Cultural Heritage 2005, 6:79-88.

9. Cennini C: I/ Libro dell'Arte. Vicenza: Neri Pozza; 1982. Chapter CLXXIV.

10. Weeks C: The Portail de la Mere Dieu of Amiens Cathedral: its polychromy and conservation. Stud Conserv 1998, 2:101-108.

11. Rager G: Un ensemble monumental en pierre polychromée du XIV ème siècle dans la cathédrale de Narbonne, Lyon. ICOM 12th Triennial Meeting 1999, 2:449-454

12. Rossi Manaresi R, Tucci A: The polychromy of the portals of the Gothic Cathedral of Bourges. Copenhagen: ICOM Seventh Triennial Meeting; 1984:84.5.1-84.5.4.

13. Rossi Manaresi R, Tucci A, Grillini GC, Nonfarmale O: Polychromed sculptures by Antelami in the Baptistry of Parma, Bologna. London: Case stud in the conservation of stone and wall paintings, IIC International Congress; 1986:66-71.

14. Nonfarmale O, Rossi M: /l restauro del Portail Royal della Cattedrale di Chartres. Arte medievale, II, first to secondth edition. Roma: Istituto dell'enciclopedia italiana; 1987:259-272.

15. Blanc A, Jaton C, Orial G: Etude des materiaux et des alterations de la façade de Notre-Dame-La-Grande de Poitiers avant restauration. Bologna: The Conservation of Stone II, International Symp; 1981:333-354.

16. Bonazzi A, Casoli A, Mangia A: Investigation of a XIII century polychromed sculpture. Ann Chim 1990, 80:423-429.

17. Andreotti A, Bonaduce I, Colombini MP, Modugno F, Ribechini E: A diagnosis of the yellowing of the marble high reliefs and the black decoration on the chapel of the tomb of Saint Anthony (Padua, Italy). Int J Mass Spectrom 2009, 284:123-130.

18. Andreotti A, Bonaduce I, Colombini MP, Gautier G, Modugno F, Ribechini E: Combined GC/MS Analytical Procedure for the Characterization of Glycerolipid, Waxy, Resinous, and Proteinaceous Materials in a Unique Paint Microsample. Anall Chem 2006, 78:4490-4500.

doi:10.1186/2050-7445-1-5

Cite this article as: Kalinina et al:: Recovery and examination of sculpture group Fugitive Slave by V. Beklemishev. Heritage Science 2013 1:5. 